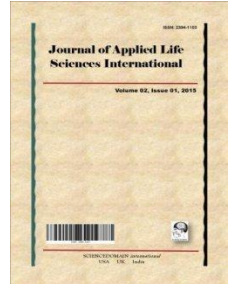

Journal of Applied Life Sciences International

6(4): 1-12, 2016; Article no.JALSI.27148

ISSN: 2394-1103

SCIENCEDOMAIN international

www.sciencedomain.org

\title{
Evaluation of Some Heavy Metals and Total Petroleum Hydrocarbon in Water and Palaemonid Shrimps (Macrobrachium vollenhovenii) of Egboko River, Warri, Delta State, Nigeria
}

\author{
Patrick Omoregie Isibor $^{1^{*}}$ and Oluowo Elohor Freeman ${ }^{1}$ \\ ${ }^{1}$ Department of Animal and Environmental Biology, Faculty of Life Sciences, University of Benin, \\ Benin City, Nigeria.
}

Authors' contributions

This work was carried out in collaboration between both authors. Author POI designed the study, performed the statistical analysis, wrote the manuscript and effected corrections from peer review. Author OEF carried out the laboratory analysis and searched for relevant literatures. Both authors read and approved the final manuscript.

Article Information

DOI: 10.9734/JALSI/2016/27148

Editor(s):

(1) Martin Koller, University of Graz, Research Management and Service, c/o Institute of Chemistry, Austria.

(2) Muhammad Kasib Khan, Department of Parasitology, University of Agriculture, Pakistan.

Reviewers:

(1) Chee Kong Yap, Universiti Putra Malaysia, Malaysia. (2) Ivana Ujevic, Institute of Oceanography and Fisheries, Croatia. (3) Steve Pothoven, National Oceanic and Atmospheric Administration, USA. Complete Peer review History: http://www.sciencedomain.org/review-history/15555

Original Research Article

Received 21 ${ }^{\text {st }}$ May 2016

Accepted $13^{\text {th }}$ July 2016

Published $28^{\text {th }}$ July 2016

\begin{abstract}
Aims: To compare the levels of heavy metals and total petroleum hydrocarbons in water and Macrobrachium vollenhovenii samples from different locations of anthropogenic activities.

Study Design: Factorial design.

Place and Duration of Study: Egbokodo River, located in Warri South Local Government Area of Delta State, Nigeria, between October, 2014 and March, 2016.

Methodology: Four (4) stations were surveyed. Station 1 (control) was located upstream and undisturbed, Station 2 had various domestic disturbances, Station 3 was disturbed with dredging activities and Station 4 was exposed to oil spill. Surface water samples were collected from each stations using $250 \mathrm{ml}$ sampling bottles and were analysed in the laboratory for heavy metals (Fe, $\mathrm{Mn}, \mathrm{Cu}, \mathrm{V}, \mathrm{Pb}$ and $\mathrm{Cd}$ ) using a Perkin Elmer 3110 model Atomic Absorption Spectrophotometer
\end{abstract}


(ASS) and total hydrocarbons (TPH) was analysed using an infrared spectrophotometer (IR-Spec) at a wavelength of about $3.425 \mu \mathrm{m}$. All values were recorded in $\mathrm{mg} / \mathrm{L}$. 30 representatives of Macrobrachium vollenhovenii were collected from each station and were digested and analysed for $\mathrm{Fe}, \mathrm{Mn}, \mathrm{Cu}, \mathrm{V}, \mathrm{Pb}, \mathrm{Cd}$ using a Perkin Elmer 3110 model Atomic Absorption Spectrophotometer (ASS), and TPH in whole shrimp was analysed using Gas chromatography with flame ionization detector (GC-FID). Data was analysed using one way analysis of variance (ANOVA) at probability level of 0.05 . Duncan multiple range test was used to detect the locations of the significant differences.

Results: The concentrations of iron and lead in the water and Macrobrachium vollenhovenii at Station $4>$ Stations 3 and $2>$ Station 1. This indicates correlation between the levels of parameters observed in the water and Macrobrachium vollenhovenii samples with the anthropogenic activities carried out at the respective locations. A constant increase in the levels of lead on advancement towards Station 4 further suggests anthropogenic impacts. The sequence of the parameters in the entire shrimp samples was $\mathrm{Fe}>\mathrm{Cu}>\mathrm{TPH}>\mathrm{V}>\mathrm{Cd}>\mathrm{Pb}>\mathrm{Mn}$; while the sequence in the water was $\mathrm{Fe}>\mathrm{TPH}>\mathrm{Cd}>\mathrm{V}>\mathrm{Cu}>\mathrm{Pb}>\mathrm{Mn}$. This sequence indicates a high affinity for iron and copper in the shrimps. This is due to the essentiality of iron in cytochromes and protein and copper in respiratory pigment haemocyanin and metalloenzyme. Distinctively high levels of cadmium, lead and total petroleum hydrocarbon observed in the tissues of Macrobrachium vollenhovenii representatives at impacted stations can be traced to the background levels in the aqueous phase.

Conclusion: Results indicate that the differences in activities at the impacted sites were associated with differences in metals among the sites and shrimp. This implies that anthropogenic activities had impacts on the aquatic equilibrium of Egbokodo River and there was corresponding response of the physiology of the palaemonid shrimps to the perturbations.

Keywords: Heavy metals; total petroleum hydrocarbon; bioaccumulation; palaemonid shrimp.

\section{INTRODUCTION}

Naturally, aquatic ecosystems receive heavy metals and hydrocarbons through biogeochemical cycle; which are often within the natural regulatory capacity of the environment. Of eco-toxicological interest are petrogenic sources of heavy metals and hydrocarbons. A vandalized oil pipeline has been a source of oil pollution to Egbokodo River for over a decade. The pollution is capable of compromising the economic, nutritional, recreational, domestic and ecological services the river renders to the dwellers of the nearby communities.

Heavy metals are minor components while petroleum hydrocarbons are major components of crude oil. Upon release of these contaminants into the aquatic ecosystem, they are incorporated in the aquatic food chain, their concentrations are biomagnified through different trophic strata; up the pyramid of biomasses. This impact ultimately culminates in the disruption of the delicate aquatic ecological equilibrium; consequently triggering innumerable eco-physiological hazards which include decreased biodiversity of finfishes and shellfishes [1,2], disruption of the reproductive systems, structural lesions and neurological disturbances in aquatic fauna etc. [3]. Apart from oil exploration activities, other activities such as dredging, recreation, boating, laundering etc. take place at the river. The distinct anthropogenic activities could be devastating and synergistically disruptive; causing greater degradation in harmony.

A number of factors work in concert to determine the rate of accumulation of these contaminants and specific sequence in finfish and shellfish. Factors that influence accumulation of heavy metals include organism's sex, age and/ or size, feeding habits, physiological roles of exposed organs, duration of exposure, metal concentration, membrane permeability and physico-chemical parameters of the river. On the other hand, the factors that influence accumulation of hydrocarbons include duration of exposure, hydrocarbon concentration and physico-chemical properties of hydrocarbons.

Palaemonid shrimps; Macrobrachium vollenhovenii (Herklots, 1851) are very abundant in the river [4]. They serve as a cheap source of animal protein to dwellers in the nearby communities. They also serve as source income for the local fishermen and other buyers from far and near. Their high are economic significance is due to their relatively large body size [5]. However this species is notorious for accumulation of contaminants; especially iron 
[6,7] from polluted environments [8]; partly due to their morphology i.e. their abdomen is not flexed beneath the thorax; hence enhances bioaccumulation of contaminants from bottom sediments and overlying water [9]. Oguzie and Ehigiator [2] observed high concentrations of nickel, iron and manganese in the Macrobrachium vollenhovenii of Ovia River and attributed it to the constant discharge of pollutants into the river.

The incessant release of petrogenic heavy metals and hydrocarbon into Egbokodo River creates possibilities of cumulative sub-lethal effects on the Macrobrachium vollenhovenii and clinical poisoning to the consumers $[9,10]$. The shrimps of the river may be exposed to some levels of risks due to the anthropogenic perturbations around the river. Worse still is the slow mobility the shrimps; hence they may remain in the polluted environment for much longer periods. Shrimps are also benthopelargic organisms which feed basically on decomposing organic matter i.e. plant and animal materials. They possess an appreciable tendency of accumulating these contaminants through the processes of bioaccumulation and biotasediment accumulation from the water and sediment matrices respectively. On these basis, they are good bio-indicators of the impact of the anthropogenic disturbances on the aquatic environment.

There is note-worthy paucity in data on bioaccumulation of total petroleum hydrocarbon in Palaemonid shrimps; hence dearth information on the bioaccumulation factors and health risk indices.

The aim of the study is to compare the levels of heavy metals and total petroleum hydrocarbons in water and Macrobrachium vollenhovenii samples from different locations of anthropogenic activities; to ascertain the level of impact on the aquatic environment.

\section{MATERIALS AND METHODS}

\subsection{Study Area}

Egbokodo River is located in Warri South Local Government Area of Delta State, Nigeria. It lies between $5^{\circ} 38^{\prime}$ and $5^{\circ} 41^{\prime} \mathrm{N} ; 5^{\circ} 36^{\prime}$ and $5^{\circ} 4^{\prime} \mathrm{E}$ (Fig. 1). The major occupations of the dwellers of the communities around the catchment areas arefarming, fishing, trading and transportation of goods and passengers along the course of the river. There are settlements at the bank of the river; especially at Stations 3 and 2. A construction company called Osas Construction Company is located close to Station 4.

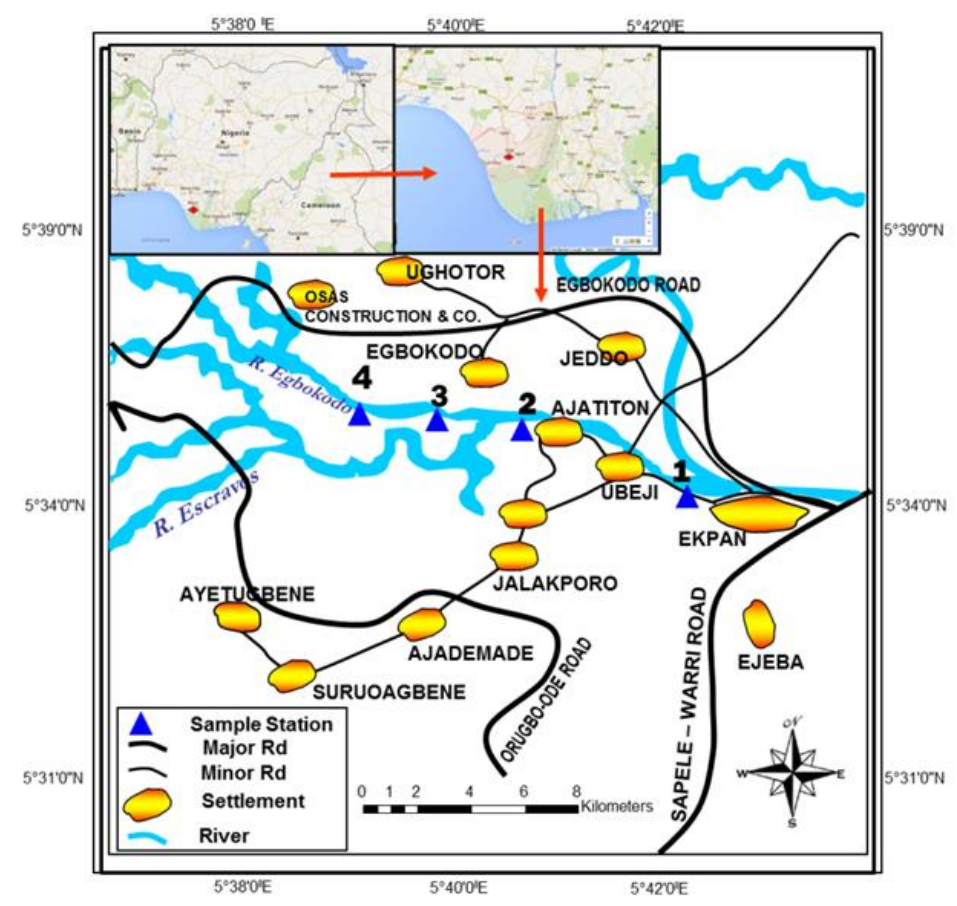

Fig. 1. Map of study area showing sampling sampled stations Source: Ministry of Lands and Survey Department, Governor's Office, Asaba, Delta State 
For the purpose of this research, four (4) stations were chosen at strategic locations. Station 1 was located far upstream; away from the disturbed locations. It witnessed minimal or negligible anthropogenic activities i.e. some fishermen were seldom observed transporting through this section of the river. Station 2 was located about 425 metres downstream from Station 1, this is a section at which many community dwellers bath, swim, defecate, dump solid wastes and carry out laundering activities [11]. Domestic activities predominate Station 2 mainly because it is free from industrial activities, hence appears to be most preferable to the community dwellers. Station 3 was located about 185 metres downstream from Station 2. Manual dredging activities carried out by a company called Osas Construction Company are predominant at this section of the river. Station 4 was located about 150 metres downstream from Station 3. Nearby this section of the river is the location of the vandalized oil pipline (point source pollution). This section of the river empties into Escravos; which ultimately discharges into the sea. The study area is dominated by bamboo trees (Bambusa species), oil palm trees (Elaeis guinensis), water hyacinths (Eichhornia crassipes) and few grasses and shrubs. The area has tropical wet climate primarily regulated by rainfall. The climate of the area consists of the rainy season from April to October while the dry season is from November to March with cold harmattan spell in December and January.

\subsection{Collection and Analysis of Samples}

Four (4) stations were surveyed for a period of 18 months (October, 2014 to March, 2016); on monthly basis. Station 1 (control) was located upstream and undisturbed, Station 2 had various domestic disturbances, Station 3 was disturbed with dredging activities and Station 4 was exposed to oil spill.

Surface water samples were collected at the four stations using $250 \mathrm{ml}$ sampling bottles; and transported immediately to the laboratory for analysis of the heavy metals which were recorded in $\mathrm{mg} / \mathrm{L}$ [12]. $100 \mathrm{ml}$ of water sample was collected in a beaker and $2 \mathrm{ml}$ nitric acid was added. The beaker was placed on a hot plate for solution evaporation and allowed to cool afterwards. The mixture was quantitatively transferred into volumetric flask. It was then allowed to settle overnight and then centrifuged until clear. After centrifuge the samples were checked for presence of suspended solids, a portion of the sample that contains suspended solids after centrifuge was filtered prior to analysis. Analysis was then carried out immediately as follows: The power button of atomic absorption spectrophotometer (AAS) system was switched on and the element hollowcathode lamp was placed in lamp holder [13]. The AAS system was allowed to warm up for about 30 minutes and the operating condition was set up as follows: Manual and auto zero mode buttons were set while selection knob was turned on PMT; whose volt was adjusted to 250 350 Volts using the ABS knob. Wavelength was set to obtain a maximum energy reading and was optimized by adjusting the vertical/horizontal lamp mount control. Flows of air and acetylene ignition were turned on and distilled water was aspirated for about 5 minutes to warm up the machine. Fuel flow was adjusted so that the ABS reading for distilled water blank was minimized to give maximum sensitivity. Auto Zero the signal by pushing the zero button. A solution of each element was then aspirated (the highest concentration) and the burner height and position were adjusted to get a maximum ABS reading. The reading of the distilled water was checked to ensure it is still close to Zero $( \pm 0.005)$. The nebulizer was adjusted and wavelength was checked when necessary to get a stable maximum signal. Water samples were then poured into auto analyzer cups and concentration of heavy metals in each was determined using the atomic absorption spectrophotometer.

Total petroleum hydrocarbon in water samples were analyzed using an infrared spectrophotometer (IR-Spec) at a wavelength of about $3.425 \mu \mathrm{m}$. A beaker was properly rinsed with distilled water and $100 \mathrm{ml}$ of water sample was poured in it. $50 \mathrm{ml}$ of dichloromethane was added to the water sample. The mixture was properly shaken and allowed to settle. A standard curve was produced using different concentrations of Escravos light crude oil (50 $\mathrm{mg} / \mathrm{L}-400 \mathrm{mg} / \mathrm{L}$ ). Samples were analyzed using an infrared spectrophotometer (IR-Spec) at a wavelength of about $3.425 \mu \mathrm{m}$. The concentration of total petroleum hydrocarbon was then calculated using the regression equation of the graph obtained from the Excravos light crude oil.

A total of 30 representatives of Macrobrachium vollenhovenii were collected from each station at low tide regime during night periods using gears such as woven cylindrical non-return valve traps, 
baskets and scoop nets; in conjunction with coconut, cassava and earthworm baits. Some were procured from fishermen and sources of such samples were properly ascertained before procurement. The samples were preserved in four different coolers with ice; appropriately labeled to indicate the source stations and were transported immediately to the laboratory, alongside water samples for identification and analysis.

Whole shrimp was digested according to standard method illustrated by Benhard [14]. 10 grams of wet weight shrimp tissue was placed in silica flasks covered with a glass plate, $20 \mathrm{ml}$ of HNO3: $\mathrm{HClO} 4$ mixture was added; ratio 5:1 respectively. Digestion process was carried out by heating the mixture at $105^{\circ} \mathrm{C}$ for about 24 hours according to [15]. The extract was made up to $25 \mathrm{ml}$ with $\mathrm{HNO}_{3}(70 \%)$ and diluted with deionized water. For quality assurance, reagent blanks were processed simultaneously in triplicates. Each residue was filtered into volumetric flask with the aid of a Whatman filter paper. The solution was tested for metals (iron, manganese, copper, vanadium, lead and cadmium) concentrations using a Perkin Elmer 3110 model Atomic Absorption Spectrophotometer (ASS) and recorded in $\mathrm{mg} / \mathrm{kg}$; wet weight [16]. In determining metal concentration, the ASS was calibrated for each metal by dissolving 1 gram analar grade metal salt in 1 litre of distilled water. Standard and corresponding blanks were run with each set of experimental digest. The detection limits of iron $(0.5 \mu \mathrm{g} / \mathrm{g})$, manganese $(0.5 \mu \mathrm{g} / \mathrm{g})$, copper $(0.05$ $\mu \mathrm{g} / \mathrm{g})$, vanadium $(0.02 \mu \mathrm{g} / \mathrm{g})$, lead $(0.03 \mu \mathrm{g} / \mathrm{g})$, and cadmium $(0.01 \mu \mathrm{g} / \mathrm{g})$ were carefully observed.

The actual concentration of metal was calculated thus:

Actual concentration of metal $=\mathrm{RD} \times$ Dilution factor [16]

$$
\begin{aligned}
& \text { Where RD = ASS reading of digest } \\
& \text { Dilution factor }=\frac{\text { Volume of digest used }}{\text { Weight of sample digested }}
\end{aligned}
$$

To test for total petroleum hydrocarbon content of samples, 10 grams wet weight shrimp tissue was placed in a $100 \mathrm{ml}$ beaker containing $60 \mathrm{ml}$ extraction mixture (acetone and dichloromethane; $1: 1)$. The content was properly agitated while heated for about 10 minutes at $70^{\circ} \mathrm{C}$; as demonstrated by Schwab, et al. [17]. The extract was decanted into a clean round bottom flask. 5 grams of sodium sulphate was added to remove water. The extract was further concentrated to $3 \mathrm{ml}$ by heating at $20^{\circ} \mathrm{C}$ [18].

Silica gel column (combination of 2 grams wool and 30 grams chromatography silica gel) was prepared and $1.5 \mathrm{ml}$ of the concentrated extract was pipetted and dropped on the silica gel column. Then $40 \mathrm{ml}$ HPLC-hexane was added to remove any organic contaminant. The silica gel columns were loaded into a Gas chromatography with flame ionization detector (GC-FID) system 6890; series model G1530. $1 \mu$ l portion of the sample was injected and analysed for TPH $\left(\mathrm{C}_{9}-\mathrm{C}_{36}\right)$. The carrier gas was purified nitrogen held at a flow rate of $5 \mathrm{ml}$ per minute. The operating temperature program was heated to $60^{\circ} \mathrm{C}$ for 2 minutes and was gradually increased at a rate of $10^{\circ} \mathrm{C}$ per minute; up to $300^{\circ} \mathrm{C}$. The procedure was maintained for about 10 minutes [19]. The oven $\left(60^{\circ} \mathrm{C}\right)$, injector $\left(250^{\circ} \mathrm{C}\right)$ and detector $\left(300^{\circ} \mathrm{C}\right)$ temperatures were constantly maintained. The minimum detection limit for total petroleum hydrocarbon was $0.1 \mu \mathrm{g} / \mathrm{kg}$ wet weight. For quality assurance, all tissue analysis results were cross checked using standard reference materials for biological samples; provided by [20].

\subsection{Statistical Analysis}

The obtained water and specimen data were analysed using SPSS package (version 19.0) and the descriptive statistics expressed as mean \pm standard deviation and range; using one way analysis of variance (ANOVA) to test for the significant difference among the groups at probability level of 0.05 . Furthermore, Duncan multiple range test was employed in ascertaining the actual locations of the significant differences; still maintaining probability level of 0.05 .

\section{RESULTS AND DISCUSSION}

\subsection{Mean Concentrations of Heavy Metals and Total Petroleum Hydrocarbon}

There was apparent correlation between the levels of parameters in the water and Macrobrachium vollenhovenii samples; these are reflections of respective anthropogenic activities at the locations. The concentrations of iron and lead in the water at Station 4 were significantly higher than that of Stations 3 and 2; which were both significantly higher than that of Station 1 $(P=0.04)$. Although their concentrations in the water of all the stations were below the Federal Ministry of Environments regulatory limits 
(20 mg/L and < $1 \mathrm{mg} / \mathrm{L}$ respectively); however the higher concentrations recorded at Stations 4 (point source of pollution crude oil pollution) can be attributed to the oil spill. Furthermore, a constant increase of lead in water samples on advancement towards Station 4 i.e. Station 1 $<$ Station $2<$ Station $3<$ Station 4 , suggests that the alterations in the water correlates with the degree of anthropogenic activities. Similar trend was observed in the tissue of Macrobrachium vollenhovenii representatives across the stations i.e. the concentrations of lead in the shrimps at Stations 4 was significantly higher than that of Station 2 and 3; which was significantly higher than Station 1 (Table 2). Though the concentrations were below regulatory limit, however anthropogenic impact is apparent. The concentration of vanadium recorded in the water of Station $2>$ Station $4>$ Station $3>$ Station 1 $(P=0.04)$. This can be attributed to the domestic solid wastes regularly dumped at this section of the river [21]. The mean concentration of sequence of vanadium in the water had some correlation with the mean concentration sequence in the tissues of the shrimps: Station 2 $>3$ and $4>$ Station $1(P=0.05)$. This suggests that the physiology of the shrimps responded accordingly to the varied levels of the parameters in the aqueous phase. Cadmium was not detected at Stations 1 and 3; which were significantly lower than Station 2, which was significantly lower than Station $4(P=0.04)$. This further buttresses the fact that anthropogenic disturbances caused alterations in specific sections of the river. The high levels of cadmium and total petroleum hydrocarbon in the water sample at Station 4 can be attributed to the oil spill.

Significantly higher concentration of iron in the tissues of Macrobrachium vollenhovenii samples from Station 4 than that of other stations i.e. Station $4>$ Station 2 and $3>$ Station $1(P=0.02)$ and regulatory limit $(1-3 \mathrm{mg} / \mathrm{kg})$ can be attributed to the oil spill at this station; coupled with its high bioaccumulation factor in Macrobrachium vollenhovenii; due to its high essentiality i.e. it is a constituent of haemoglobin. Results show that Macrobrachium vollenhovenii at all stations appreciably accumulated copper; compared to the levels observed in the water samples. This is due to the high threshold of essentiality of copper in the shrimps; it is highly required in their respiratory pigment haemocyanin [8] and also a constituent of metalloenzymes involved in vital metabolic activities. Copper is also essential in nourishment and replacement of worn-out tissues in the organism. Distinctively high levels of cadmium, lead and total petroleum hydrocarbon observed in the tissues of Macrobrachium vollenhovenii representatives at Station 4 (Table 2) can be traced to the background levels in the aqueous phase (Table 1); due to the oil spill incidence. Significantly higher concentrations of the nonessential metals (cadmium and lead) and total petroleum hydrocarbon observed in the water and Macrobrachium vollenhovenii representatives from Station 4 than other stations $(P=0.05)$ shows that the anthropogenic activities at this river has impacts on the aquatic ecosystem. Concentration of iron and total petroleum hydrocarbon observed in Macrobrachium vollenhovenii from Station 4 far exceeds the regulatory limit (1- 3 and $2 \mathrm{mg} / \mathrm{kg}$ respectively).

The sequence of the parameters in the entire shrimp samples was $\mathrm{Fe}>\mathrm{Cu}>\mathrm{TPH}>\mathrm{V}>\mathrm{Cd}$ $>\mathrm{Pb}>\mathrm{Mn}$; while the sequence in the water was $\mathrm{Fe}$ $>\mathrm{TPH}>\mathrm{Cd}>\mathrm{V}>\mathrm{Cu}>\mathrm{Pb}>\mathrm{Mn}$. This sequence indicates a high affinity for iron and copper in the shrimps. This is due to the essentiality of iron in cytochromes and protein [7] and the high affinity for copper can be attributed to its function in respiratory pigment haemocyanin [22] and metalloenzyme [6]. This finding is consistent with the sequence observed by Omoigberale and Ikponmwosa- Eweka [8] in the palaemonid shrimps of Osse River: $\mathrm{Fe}>\mathrm{Mn}>\mathrm{Cu}>\mathrm{Zn}>\mathrm{Pb}>$ $\mathrm{Cd}>\mathrm{Cr}$. Higher level of manganese than copper in the palaemonid shrimps of Osse River; contrary to that of Egbokodo River can be traced to high level in the water of Osse River: $\mathrm{Fe}>\mathrm{Mn}>$ $\mathrm{Zn}>\mathrm{Cu}>\mathrm{Pb}$. The current findings is also at variance with the high level of manganese observed in the Macrobrachium vollenhovenii of Ovia River by Oguzie and Ehigiator [2]; which was attributed it to the constant discharge of pollutants into the river. This shows that palaemonid shrimps are quite vulnerable to the background levels of contaminants.

Only cadmium concentrations in the water and shrimps of Station 4 exceeded FEPA regulatory limits (Fig. 7). Regulation of the anthropogenic activities and constant bio-monitoring of the aquatic environment are strongly recommended in order to prevent future surge in parameter levels. Immediate regulation of the anthropogenic activities and constant bio-monitoring of the aquatic environment are strongly recommended in order to prevent future surge in parameter levels. 
Table 1. Summary of heavy metals $(\mathrm{mg} / \mathrm{L})$ and total petroleum hydrocarbon $(\mathrm{mg} / \mathrm{L})$ in water of Egbokodo River

\begin{tabular}{|c|c|c|c|c|c|c|c|}
\hline Parameters & $\mathbf{N}$ & Station $1 \pm$ S.E (Range) & Station $2 \pm$ S.E (Range) & Station $3 \pm$ S.E (Range) & Station $4 \pm$ S.E (Range) & $P$ & FEPA \\
\hline $\mathrm{Fe}$ & 18 & $0.08 \pm 0.02^{C}(0.01-0.25)$ & $0.60 \pm 0.06^{\mathrm{B}}(0.07-0.81)$ & $0.49 \pm 0.08^{\mathrm{B}}(0.06-0.86)$ & $4.07 \pm 0.37^{A}(2.34-6.86)$ & ${ }^{*} P=0.04$ & 20 \\
\hline $\mathrm{Mn}$ & 18 & $0.01 \pm 0.003(0-0.04)$ & $0.01 \pm 0.003(0-0.06)$ & $0.04 \pm 0.02(0-0.23)$ & $0.04 \pm 0.01(0-0.10)$ & $P=0.74$ & 0.5 \\
\hline $\mathrm{Cu}$ & 18 & $0.12 \pm 0.04(0-0.41)$ & $0.39 \pm 0.08(0.02-0.86)$ & $0.41 \pm 0.09(0.02-0.91)$ & $0.48 \pm 0.08(0.01-0.86)$ & $P=0.72$ & $<1$ \\
\hline $\mathrm{V}$ & 18 & $0.01 \pm 0.007^{\mathrm{D}}(0-0.04)$ & $1.04 \pm 0.3^{\mathrm{A}}(0.66-1.43)$ & $0.24 \pm 0.17^{\mathrm{C}}(0.04-0.55)$ & $0.69 \pm 0.13^{B}(0.06-1.51)$ & ${ }^{*} P=0.04$ & $<1$ \\
\hline $\mathrm{Pb}$ & 18 & $N D^{C}$ & $0.05 \pm 0.004^{\mathrm{B}}(0.04-0.10)$ & $0.06 \pm 0.007^{B}(0.03-0.10)$ & $0.75 \pm 0.005^{\AA}(0.58-1.05)$ & ${ }^{*} P=0.04$ & $<1$ \\
\hline $\mathrm{Cd}$ & 18 & $N D^{C}$ & $0.03 \pm 0.008^{B}(0-0.09)$ & $\mathrm{ND}^{\mathrm{C}}$ & $2.86 \pm 0.13^{\mathrm{A}}(2.26-3.88)$ & ${ }^{*} P=0.04$ & $<1$ \\
\hline TPH & 18 & $\mathrm{ND}^{\mathrm{C}}$ & $0.004 \pm 0.001^{\mathrm{B}}(0-0.01)$ & $0.007 \pm 0.001^{\mathrm{B}}(0-0.01)$ & $3.69 \pm 0.19^{A}(2.82-5.02)$ & ${ }^{*} P=0.03$ & 10 \\
\hline
\end{tabular}

NOTE: $P$ value less than or equal to 0.05 signifies significant difference, while values greater than 0.05 signifies no significant difference. Different letters indicate significant differences, while similar letters indicate no significant differences ND means not detected, TPH means total petroleum hydrocarbon, FEPA means Federal Environmental

$$
\text { Protection Agency [20] }
$$

Table 2. Summary of heavy metals ( $\mathrm{mg} / \mathrm{kg}$ wet weight) and total petroleum hydrocarbon (mg/kg wet weight) in Macrobrachium vollenhovenii of Egbokodo River

\begin{tabular}{|c|c|c|c|c|c|c|c|}
\hline Parameters & $\mathbf{N}$ & Station $1 \pm$ S.E (Range) & Station $2 \pm$ S.E (Range) & Station $3 \pm$ S.E (Range) & Station $4 \pm$ S.E (Range) & $P$ & FAO/ FEPA \\
\hline $\mathrm{Fe}$ & 18 & $0.16 \pm 0.03^{C}(0.02-0.32)$ & $1.8 \pm 0.04^{\mathrm{B}}(0.3-3.8)$ & $0.32 \pm 0.05^{C}(2.54-5.55)$ & $22.58 \pm 3.92^{\mathrm{A}}(2.28-48.23)$ & ${ }^{*} P=0.02$ & 100.00 \\
\hline $\mathrm{Mn}$ & 18 & $0.03 \pm 0.01(0.01-0.08)$ & $0.05 \pm 0.005(0.02-0.08)$ & $0.05 \pm 0.007(0.01-0.09)$ & $0.04 \pm 0.005(0.02-0.08)$ & $P=0.72$ & 1.00 \\
\hline $\mathrm{Cu}$ & 18 & $1.59 \pm 0.15^{\mathrm{B}}(0.45-2.21)$ & $3.39 \pm 0.12^{B}(2.82-4.09)$ & $4.75 \pm 0.25^{\mathrm{A}}(3.24-6.88)$ & $6.78 \pm 0.27^{\mathrm{A}}(3.02-6.75)$ & ${ }^{*} P=0.05$ & 3.00 \\
\hline V & 18 & $0.04 \pm 0.01^{c}(0.01-0.09)$ & $2.47 \pm 0.3^{A}(0.92-4.08)$ & $1.85 \pm 0.17^{\mathrm{B}}(0.45-2.87)$ & $1.38 \pm 0.13^{B}(0.57-2.07)$ & ${ }^{*} P=0.05$ & - \\
\hline $\mathrm{Pb}$ & 18 & $0.04 \pm 0.004^{C}(0.02-0.06)$ & $0.05 \pm 0.004^{B}(0.03-0.08)$ & $0.05 \pm 0.003^{B}(0.04-0.07)$ & $0.88 \pm 0.08^{A}(0.47-1.86)$ & ${ }^{*} P=0.05$ & 2.00 \\
\hline $\mathrm{Cd}$ & 18 & $N D^{C}$ & $0.04 \pm 0.01^{\mathrm{B}}(0-0.09)$ & $N D^{C}$ & $4.24 \pm 0.31^{\mathrm{A}}(3.22-6.88)$ & ${ }^{*} P=0.05$ & 2.00 \\
\hline TPH & 18 & $N D^{C}$ & $0.79 \pm 0.23^{\mathrm{B}}(0.02-2.54)$ & $0.24 \pm 0.05^{\mathrm{B}}(0.01-0.71)$ & $8.7 \pm 1.85^{\mathrm{A}}(1.34-23.58)$ & ${ }^{*} P=0.04$ & 2.00 \\
\hline
\end{tabular}

NOTE: $P$ value less than or equal to 0.05 signifies significant difference, while values greater than 0.05 signifies no significant difference. Different letters indicate significant differences, while similar letters indicate no significant differences ND means not detected, TPH means total petroleum hydrocarbon, FAO and WHO mean Food and Agricultural Organization [23] and Federal Environmental Protection Agency [20] respectively 


\subsection{Bioaccumulation in Macrobrachium vollenhovenii}

Continuous lines in the graphs indicate the permissible limits in shrimps, while broken lines indicate the permissible limits in the water. Unindicated limits are either out of range or unavailable (vanadium; Fig. 4). Result shows accumulation of iron (Fe) by the Macrobrachium vollenhovenii samples of Station 4 . There was a progressive increase of iron in water and Macrobrachium vollenhovenii representatives from Station 1 towards Station 4 . This can be attributed to significant impact of the crude oil point source pollution at Station 4 (Fig. 2).
The essentiality of manganese was reflected in all the representatives of Macrobrachium vollenhovenii across all the stations; including the control station; Station 1 (Fig. 3).

There is discernible correlation between bioaccumulation of vanadium observed in the Macrobrachium vollenhovenii representatives from each station with the concentrations in the water of each station i.e. bioaccumulation rate is directly proportional to the concentrations of vanadium (Fig. 4). This clearly shows that the concentration of bioavailable metals is one of the factors that influence their accumulation.

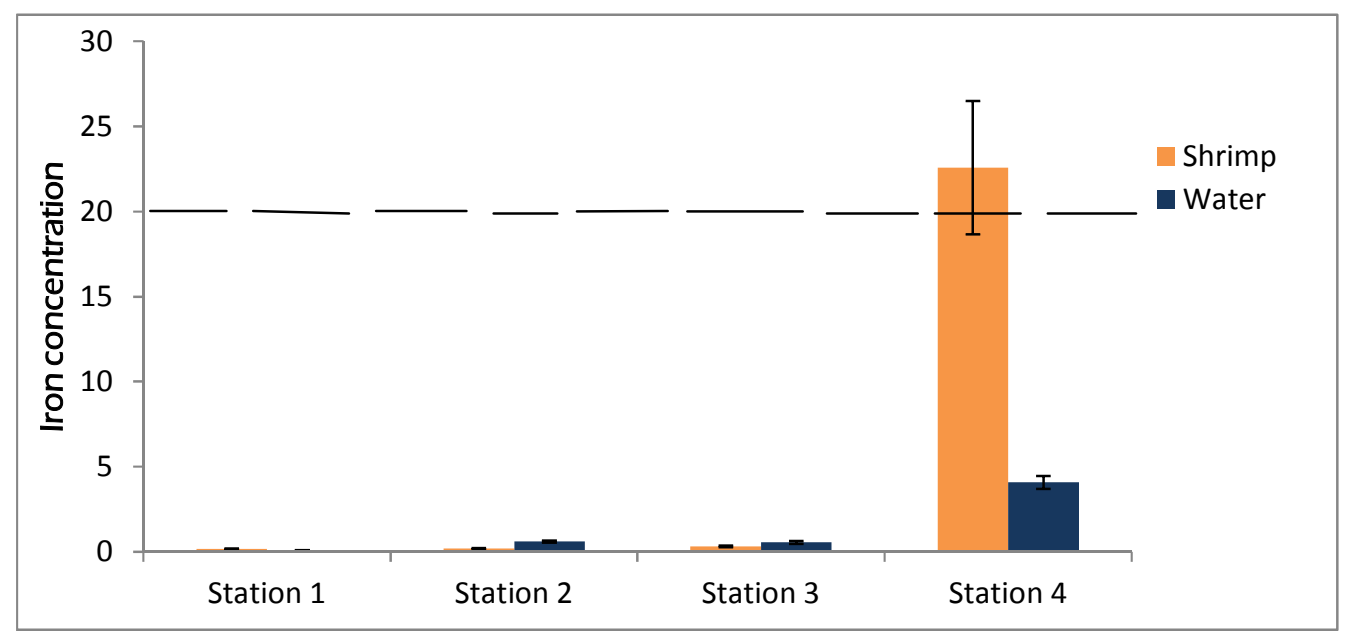

Fig. 2. Spatial distribution of iron in water and Macrobrachium vollenhovenii Note: Iron concentration is in $\mathrm{mg} / \mathrm{L}$ in water and $\mathrm{mg} / \mathrm{kg}$ wet weight in Macrobrachium vollenhovenii

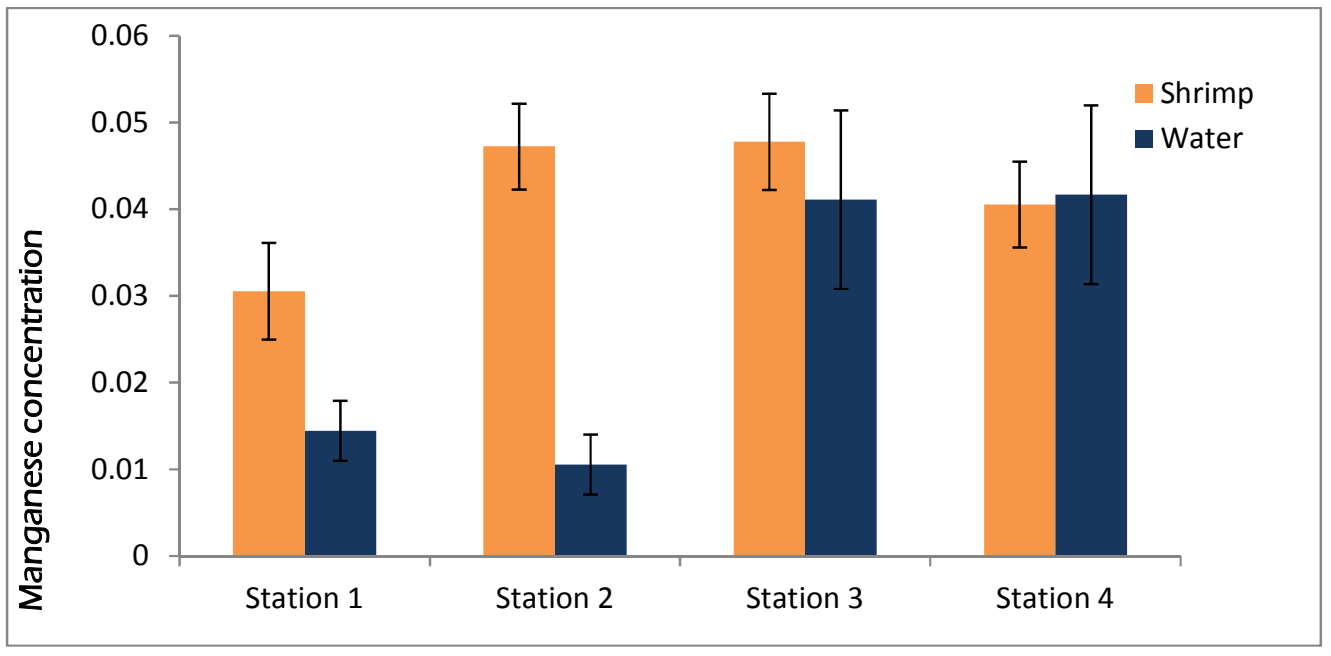

Fig. 3. Spatial distribution of manganese in water and Macrobrachium vollenhovenii Note: Manganese concentration is in $\mathrm{mg} / \mathrm{L}$ in water and $\mathrm{mg} / \mathrm{kg}$ wet weight in Macrobrachium vollenhovenii 
There is constant increase in the bioaccumulation of copper in Macrobrachium vollenhovenii representatives towards Station 4 i.e. Station $4>$ Station $3>$ Station $2>$ Station 1 (Fig. 5). It can be further deduced that the shrimps exhibit appreciable bioaccumulation of copper; due to the essentiality of the metal.

The species exhibited poor bioaccumulation of lead and cadmium (Figs. 6 and 7 respectively). High levels were however recorded only in representatives that had high levels of exposure in the aqueous phase i.e. Station 4. The low accumulation of lead and cadmium can be attributed to their non-essentiality. Relatively high levels of lead, cadmium and total petroleum hydrocarbon recorded in the water samples; hence Macrobrachium vollenhovenii representatives therein; at Station 4 can be attributed to the oil spill which occurred at the station.

At Station 4, the Macrobrachium vollenhovenii samples accumulated total petroleum hydrocarbons (TPH) beyond permissible limit (Fig. 8). This can be attributed to oil spill at this section of the river. On station comparison basis, accumulation of TPH was Station $4>$ Station $2>$ Station $3>$ Station 1 .

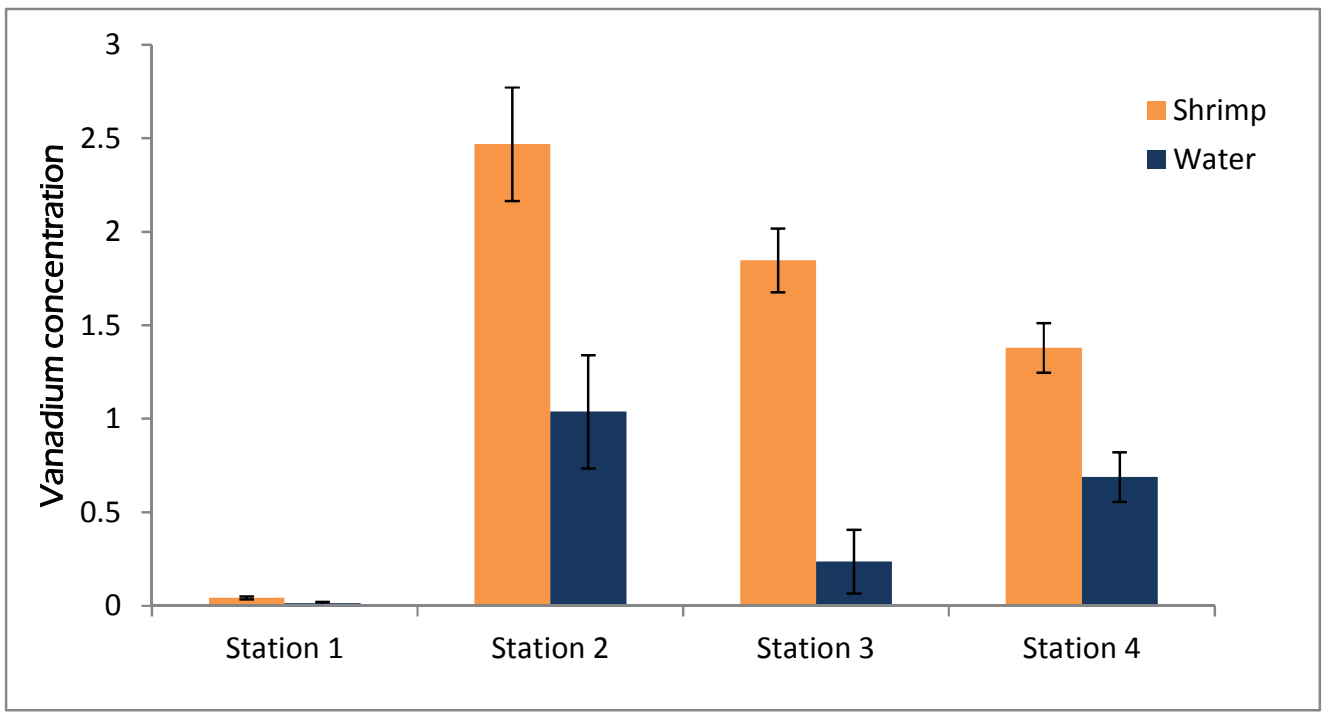

Fig. 4. Spatial distribution of vanadium in water and Macrobrachium vollenhovenii Note: Vanadium concentration is in $\mathrm{mg} / \mathrm{L}$ in water and $\mathrm{mg} / \mathrm{kg}$ wet weight in Macrobrachium vollenhovenii

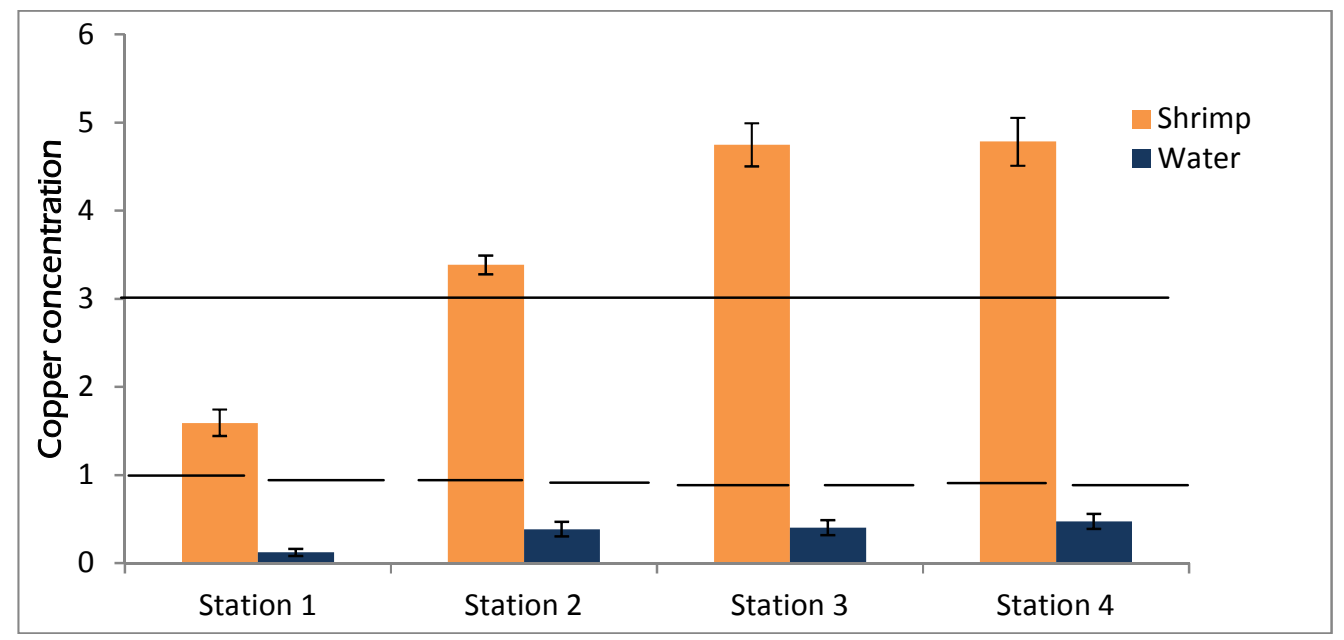

Fig. 5. Spatial distribution of copper in water and Macrobrachium vollenhovenii Note: Copper concentration is in $\mathrm{mg} / \mathrm{L}$ in water and $\mathrm{mg} / \mathrm{kg}$ wet weight in Macrobrachium vollenhovenii 


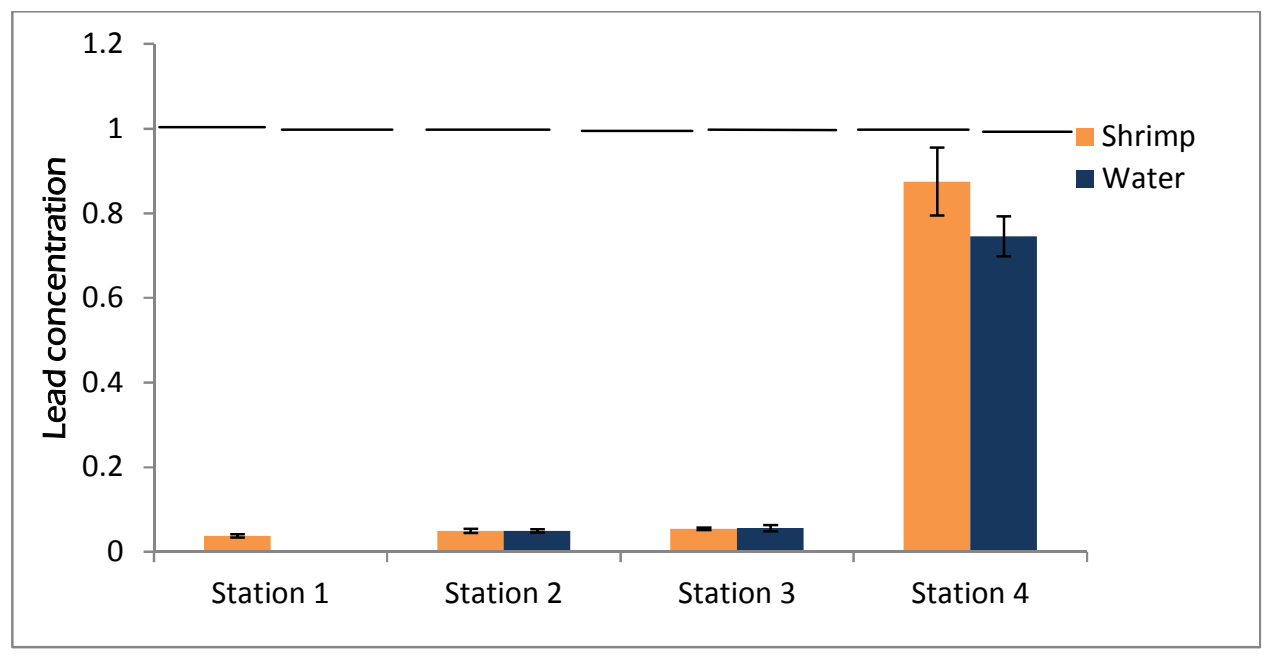

Fig. 6. Spatial distribution of lead in water and Macrobrachium vollenhovenii Note: Lead concentration is in $\mathrm{mg} / \mathrm{L}$ in water and $\mathrm{mg} / \mathrm{kg}$ wet weight in Macrobrachium vollenhovenii

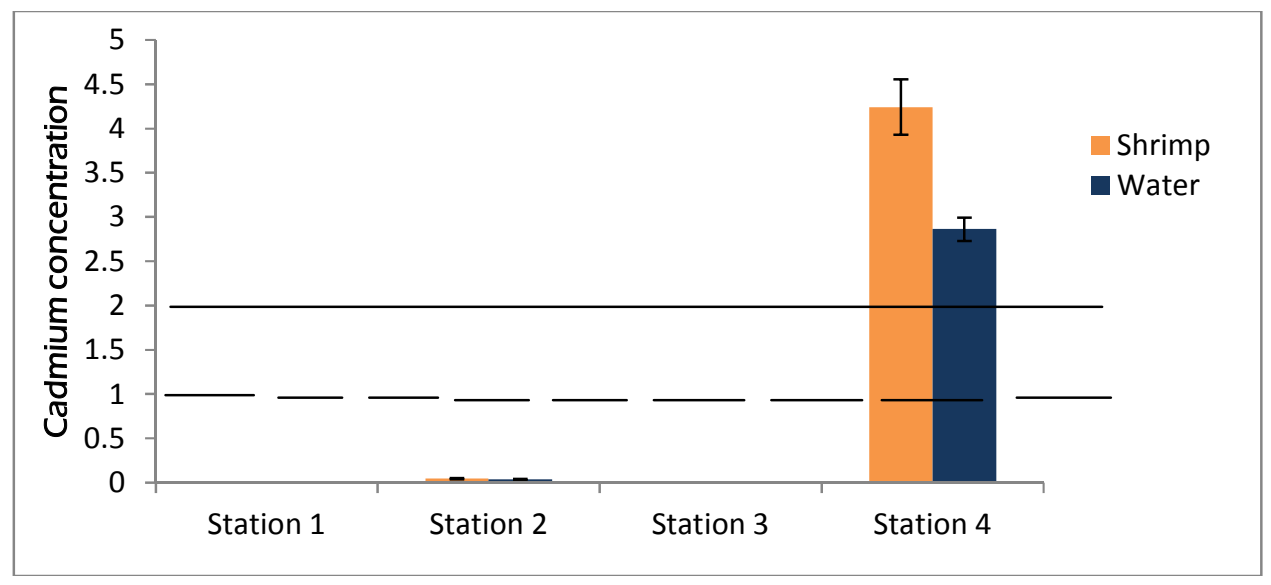

Fig. 7. Spatial distribution of cadmium in water and Macrobrachium vollenhovenii Note: Cadmium concentration is in $\mathrm{mg} / \mathrm{L}$ in water and $\mathrm{mg} / \mathrm{kg}$ wet weight in Macrobrachium vollenhovenii

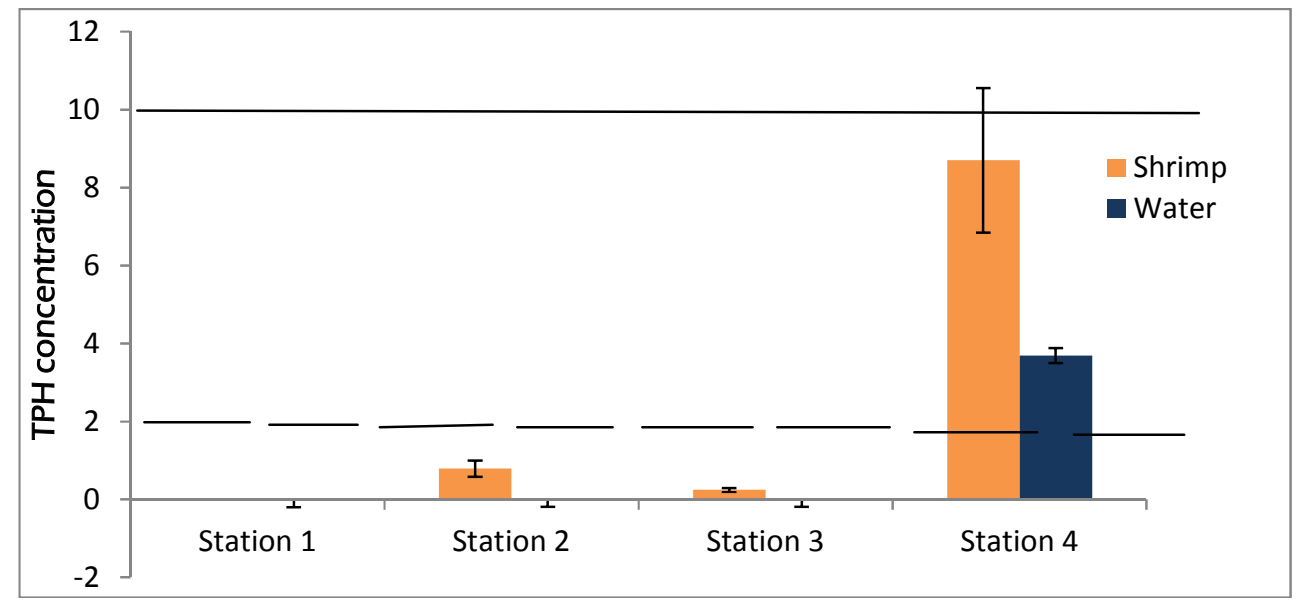

Fig. 8. Spatial distribution of TPH in water and Macrobrachium vollenhovenii Note: TPH concentration is in $\mathrm{mg} / \mathrm{L}$ in water and $\mathrm{mg} / \mathrm{kg}$ wet weight in Macrobrachium vollenhovenii 


\section{CONCLUSION}

The overall physico-chemistry of the shrimps and water samples were within regulatory limits; except for high levels of cadmium in shrimps and water of Station 4. Results indicate that the differences in activities at the impacted sites were associated with differences in metals among the sites and shrimps. This implies that anthropogenic activities had impacts on the aquatic equilibrium of Egbokodo River and there was corresponding response of the physiology of the palaemonid shrimps to the perturbations. Remediation processes should be carried out alongside continuous bio-monitoring of the aquatic environment in order to forestall the cumulative effects of the pollutants which may pose threats such as sub-lethal effects to the aquatic fauna and clinical poisoning to the consumers in the future [24].

\section{ACKNOWLEDGEMENTS}

A big gratitude is reserved for the parents of the Corresponding Author; Chief and Mrs. W.P.O. Isibor for their selfless financial support.

\section{COMPETING INTERESTS}

Authors have declared that no competing interests exist.

\section{REFERENCES}

1. Anetekhai MA, Akin-Arinola, Aderinola OJ, Akintola SL. Trace metal concentration in Macrobrachium vollenhovenii from Ologe Lagoon, Lagos, Nigeria. J. Afrotrop. Zool. 2007;(Special Issue):25-29.

2. Oguzie FA, Ehigiator FAR. Concentration of heavy metals in three African prawn (Crustacea: Palaemonidae) from Osse River in Edo State, Nigeria. J. Agric. Sc. Env. 2011;11(1):104-113.

3. Javed $M$, Usmani $N$. Accumulation of heavy metals in fishes: A human health concern. International Journal of Environmental Sciences. 2011;2:2.

4. Ashraj W. Accumulation of heavy metals in kidney and heart tissues of Epinephelus micodon fish from the Arabian gulf. Environmental Monitoring Assessment. 2005;101;(1-3):311-316.

5. American Public Health Association (APHA). Standard methods for examination of water and waste water. $20^{\text {th }}$ Edition APHA - AWNA- WPCF. New York, USA. 1998;1134.
6. De Silva SS, Anderson TA. Fish nutrition in aquaculture. $1^{\text {st }}$ Edition. London. Chapman and Hall; 1995.

7. Edema U, Egborge ABM. Heavy metal content of Macrobrachium species (Crustacea: Palaemonidae) from Warri River, Nigeria. Tropical Journal of Environment, Science and Health. 1999;2 (1):65-70.

8. Omoigberale MO, Ikponmwosa-Eweka O. Evaluation of heavy metals of the Palaemonid shrimps (Macrobrachium vollenhovenii) in Osse River, Nigeria. Bioscience Research Communications. 2010;22(5).

9. Egborge ABM. Water pollution in Nigeria: Biodiversity and chemistry of Warri River. $1^{\text {st }}$ Edition. Warri, Ben Miller Book. $1994 ; 331$.

10. Jezierska B, Witeska M. The metal uptake and accumulation in fish living in polluted waters. Twardowska I, et al. (eds.). Soil and Water Pollution Monitoring, Protection and Remediation. 2006;3-23.

11. Bello-Olusoji A, Ariyo TO, Arinola A. Taxonomical studies on rocky freshwater prawns at erin-ijesha waterfalls. Journal of Food, Agricultural and Environment. 2004; 2(3\&4):280-283.

12. American Public Health Association (APHA). American water works association. Water pollution control federation. Standard Methods for the Examination of Water and Wastewater, $13^{\text {th }}$ Edition; 1992.

13. Van Loon JC. Analytical atomic spectroscopy. Selected methods. Academic Press, New York. 1980;337.

14. Benhard M. Manual of methods in the aquatic environment research. FAO. Fisheries technical paper FIRI/T. Number 158, Food and Agricultural Organization, Rome; 1976.

15. Turkmen G. Seasonal variation in heavy metals in shrimps Penaeus kerathurus (Forskal, 1775) from Izmir Bay. J. Amin. Vet. Adv. 2012;11(15):2839.

16. Olaifa FE, Olaifa AK, Adelaja AA, Owolabi AG. Heavy metal contamination of Clarias gariepinus from lake and fish farm in Ibadan, Nigeria. Afr. J. Biomed. Res. 2004; 7:145-148.

17. Schwab AP, Su J, Wetzel S, Pekare S, Banks MK. Extraction of petroleum hydrocarbons from soil by mechanical 
shaking. Environmental Science and Technology. 1999;33:1940-1945.

18. Webster L. Long term monitoring of polycyclic aromatic hydrocarbons in mussels (Mytilus edulis) following the braer oil spill. 1997;122:191-195.

19. American Petroleum Institute (API). API recommended practice for analysis of oil field water. APR - RP - 45, API Dallas Texas; 1968.

20. Federal Environmental Protection Agency (FEPA). Guidelines and Standards for Environmental Pollution Control in Nigeria. 2003;237-240.

21. Ikejimba CC, Sakpa S. Comparative study of some heavy metals' concentrations in water and Tympanotonus fuscatus var radula samples of Egbokodo River, Warri, Nigeria. International Journal of Modern
Biological Research (Int. Mod. Biol. Res.). IJMBR. 2014;2:7-15.

22. Van de Broek WLF. Seasonal levels of chlorinated hydrocarbons and heavy metals in fish and brown shrimps from the Medway Estuary Kent. Environmental Pollution. 1979;19:21-28.

23. Food and Agricultural Organization (FAO). Compilation of legal limits of hazardous substances in fish and fishery products. FAO. Fisheries Circular Number. 1983; 464:5-100.

24. Agency for Toxic Substances and Disease Registry (ATSDR). Toxicological profile for polyaromatic hydrocarbons (PAH) in Goldstein BD, et al. 2011. The gulf oil spill. New England Journal of Medicine. 2010; 364(14):1334-1348.

(c) 2016 Isibor and Freeman; This is an Open Access article distributed under the terms of the Creative Commons Attribution License (http://creativecommons.org/licenses/by/4.0), which permits unrestricted use, distribution, and reproduction in any medium, provided the original work is properly cited.

Peer-review history:

The peer review history for this paper can be accessed here: http://sciencedomain.org/review-history/15555 